Article

\title{
Evaluation on Overheating Risk of a Typical Norwegian Residential Building under Future Extreme Weather Conditions
}

\author{
Zhiyong Tian ${ }^{1, * \mathbb{C}}$, Shicong Zhang ${ }^{2}$, Jie Deng ${ }^{3} \mathbb{C}$ and Bozena Dorota Hrynyszyn ${ }^{1} \mathbb{C}$ \\ 1 Department of Civil and Environmental Engineering, Norwegian University of Science and Technology, \\ 7491 Trondheim, Norway; bozena.d.hrynyszyn@ntnu.no \\ 2 Institute of Building Environment and Energy, China Academy of Building Research, Beijing 100013, China; \\ zhangshicong01@126.com \\ 3 School of the Built Environment, University of Reading, Reading RG6 6DF, UK; deng-jie2@163.com \\ * Correspondence: tianzy0913@163.com or zhiyong.tian@ntnu.no
}

Received: 28 November 2019; Accepted: 27 January 2020; Published: 4 February 2020

\begin{abstract}
As the temperature in the summer period in Norway has been always moderate, little study on the indoor comfort of typical Norwegian residential buildings in summer seasons can be found. Heat waves have attacked Norway in recent years, including in 2018 and 2019. Zero energy buildings, even neighborhoods, have been a hot research topic in Norway. There is overheating risk in typical Norwegian residential buildings without cooling devices installed under these uncommon weather conditions, like the hot summers in 2018 and 2019. Three weather scenarios consisting of present-day weather data, 2050 weather data, and 2080 weather data are investigated in this study. The overheating risk of a typical Norwegian residential building is evaluated under these three weather scenarios. 72 scenarios are simulated in this study, including different orientations, window-to-wall ratios, and infiltration rates. Two different overheating evaluation criteria and guidelines, the Passive House Planning Package (PHPP) and the CIBSE TM 59, are compared in this study.
\end{abstract}

Keywords: overheating risk; evaluation; indoor comfort; cold climates

\section{Introduction}

Since the Energy Performance of Buildings Directive (EPBD) was published in 2010, low energy building has become a hot topic in Europe. In June 2018, the EPBD was revised. Health and well-being of building users is promoted under the new revised EPBD (2018/844/EU).

Unusually hot weather occurred in many European countries in the summers of 2018 and 2019. In northern Europe, from Ireland to the Baltic countries through southern Scandinavia, the outdoor temperatures have risen by $3-6^{\circ} \mathrm{C}$ above average. All previous temperature records were broken in many weather stations of northern Europe in May, 2018. In Norway, the outdoor temperature in 2018 was $4{ }^{\circ} \mathrm{C}$ hotter than that in previous years. The year 2018 was the third hottest on record, which underlined "the clear warming trend" in the last four decades [1]. Many Norwegian cities have recorded temperatures in excess of $30^{\circ} \mathrm{C}$, up to $35.6{ }^{\circ} \mathrm{C}$ in the summer of 2019 . Hot summer such as that in 2018 is predicted to become common by 2050 [2]. High temperatures linked to climate changes and heat waves are already causing premature deaths in northern Europe. The heat-related mortality will be more serious if high temperature weather is more and more common in the near future. For instance, more than 1500 people have died from heat waves in all of Sweden in recent decades [3].

Normally there are few installations of cooling devices, even electrical fans, in the household in the Nordic area, including Norway. Many residents felt very uncomfortable indoors in the hot 
summers of 2018 and 2019 because of the lack of cooling devices. In general, there are no efficient shading facilities in Norwegian residential buildings. Most of the current venetian blinds in the household are just for glare prevention. As far as we know, there are no publications which evaluate the overheating risk of residential buildings in Norway built today, while this problem is taking place more and more frequently.

Many researchers have carried out investigations of overheating risk in apartments. Pathan et al. [4] found that there was a significant risk of overheating based on the measurements from 122 residential buildings in London in the summers of 2009 and 2010. Jenkins et al. [5] simulated the domestic overheating of a dwelling under different climate scenarios for the different locations in UK. Bertug Ozarisoy assessed the overheating risk issues of a typical house during the heatwave period in the England [6]. The monitoring data in the summer of 2018 showed that there was a heavy overheating risk and discomfort in many occupied spaces. Masoud et al. [7] investigated the overheating risk of social housing flats built to passive house standards in the UK. It was found that more than two-thirds of flats had the overheating exceeding the benchmark. Ji et al. [8] created a simulation of overheating risk of a typical house in Manchester under future weather scenarios. Gupta et al. [9] suggested that attention should be paid to the overheating risk in the south-east of England in the future. They found that the most effective (passive) solutions for reducing future overheating were to improve envelope and decrease internal heat gains. Peacock et al. [10] investigated the possible overheating risk in UK dwellings for the future climate change. It was predicted that $18 \%$ of the dwellings in the south of England had to install domestic air conditioners by 2030.

Psomas et al. [11] determined the overheating risk of retrofitting of single-family buildings and found that ventilation and shading systems were useful for reducing overheating. Most of the studies mentioned focus on the overheating risk in the south-east of England. Furthermore, Ibrahim et al. [12] highlighted the overheating risk of a retrofitted residential building in Sheffield, in the north of England. It was suggested that solar shading systems and night ventilation systems were the most effective passive overheating strategies. Sehizadeh et al. [13] investigated the influence of possible climate changes on the overheating of a house retrofitted to the international EnerPHit standard in Canada. It was found that the overheating risk of a typical house retrofitted to the international EnerPHit standard would significantly increase in the near future. Grussa et al. [14] evaluated the use of solar shading and night ventilation in a residential retrofit case study located in London in order to reduce the overheating risk. They concluded that night ventilation and shading systems during the daytime could decrease the overheating risk significantly. Salem et al. [15] investigated the impacts of changing weather conditions on the overheating risk and energy performance for a village adapted to the nearly zero energy building standards in the UK. It was shown that night ventilation, double glazing (low-e) windows, and shading devices were not enough to reduce the overheating risk.

Mitchell et al. [16] analyzed the overheating risk of UK passive residential buildings by collecting high-resolution indoor temperature data from 82 homes across the UK. It was suggested that the overheating should be identified in individual rooms, not at the whole-building level. Petrou et al. [17] investigated the indoor temperatures of English buildings. 26\% of the residential buildings monitored had overheating. Roberts et al. [18] analyzed the overheating risk with the dynamic thermal models.

Figure 1 shows the land surface temperature difference compared to the average temperature for the period of 2000-2015. It can be seen that the temperature in most of southern Norway in the summer season of 2018 was $5{ }^{\circ} \mathrm{C}$ higher than that in normal years. Temperatures of $35^{\circ} \mathrm{C}$ outside will result in an uncomfortable indoor environment. There are several publications on the overheating risk in southern Europe. Mlakar et al. [19] identified different energy gains and the impact factors on the overheating risk in a passive building in Slovenia. The results showed that night ventilation in the summer seasons, shading, and reduction of the inter heat gains were enough to decrease the overheating risk. Overheating discomfort also may be one of the unintended consequences in the building sector even in Norway, while the extreme heat waves in the summer will happen more 
frequently in the future. No publications on this topic in Norway have been published, as far as we know.

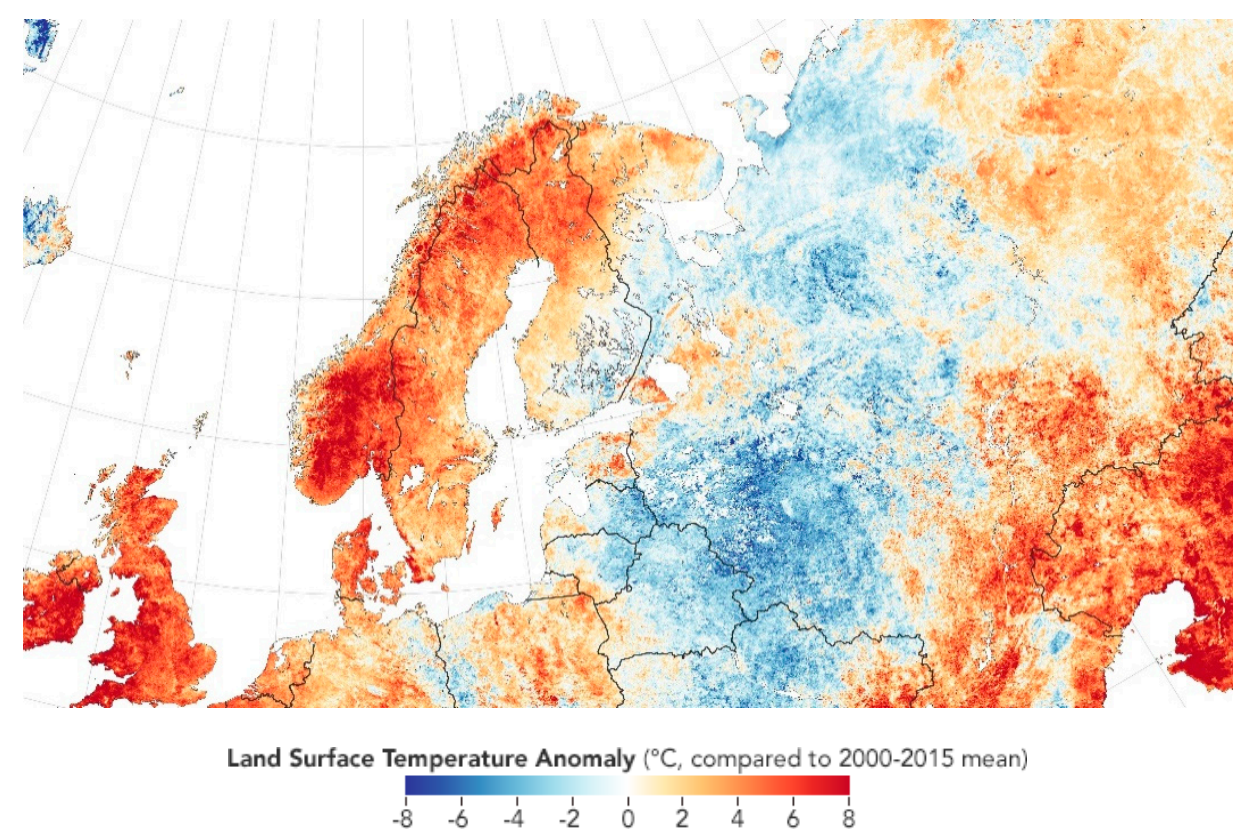

Figure 1. Temperature anomaly in Northern Europe in July (Source: NASA).

A building simulation model based on a typical residential building built in Norway, according to the Norwegian building code (Pbl/TEK17), was set up in the computer-aided design (CAD) application software Rhinoceros®(Robert McNeel \& Associates, Seattle, WA, USA). The Energy Plus platform was used to do energy calculations. The overheating risk of a typical Norwegian residential building in the summer under different weather scenarios was determined in this paper. Three weather scenarios consisting of present-day weather data, $2050 \mathrm{~s}$ weather data and $2080 \mathrm{~s}$ weather data were investigated. The overheating risk of a typical Norwegian residential building under three weather scenarios was evaluated. Different orientations, window-to-wall ratios, and infiltration rates were simulated. Two different overheating evaluation criterial guidelines, including the Passive House Planning Package (PHPP) and the CIBSE TM 59, were compared in this study. The results can provide some design basis for architects and real estate developers in Norway.

\section{Method}

\subsection{Simulation Tool}

Geometry of the simulated building was drawn in the Rhinoceros 5.0. Building performance simulation was carried out in Energy Plus engine via Ladybug and Honeybee plugins.

CCWorldWeatherGen tool was used to generate the future weather parameters in the 2050 and 2080 scenarios. The output data of the HadCM3 was combined with the Intergovernmental Panel on Climate Change (IPCC) A2 emission scenario through the morphing method to generate future EnergyPlus weather files.

\subsection{Evaluation Criteria and Guideline}

\subsubsection{Passive House Planning Package (PHPP)}

The Passive House Planning Package has been developed by the Passive House Institute in Darmstadt. The PHPP methodology defines the risk of overheating of a building by the percentage of 
the hours when the indoor temperature is higher than a limit value during one whole year. The default limit value is $25^{\circ} \mathrm{C}$. The comfort range is $10 \%$.

\subsubsection{CIBSE TM 59 (Adaptive Thermal Comfort)}

The Predicted Mean Vote (PMV), developed by Povl Ole Fanger (1970), has been widely used in many standards to describe thermal comfort of mechanically heated/cooled spaces. Many parameters, including indoor environment parameters, metabolic rate and clothing insulation were considered in the PMV.

Developed for commercial buildings, Technical Memorandum 52 (TM52) is based on BS EN 15251:2007. The method of overheating evaluation in CIBSE TM59 Design Methodology was amended from the CIBSE TM52. The bedrooms should meet two requirements. The first criterion for the bedrooms is that the number of hours when temperature difference is bigger than or equal to one degree (K) from May to September shall not be more than 3\% of the occupied hours.

$$
\begin{gathered}
\Delta T=T_{o p}-T_{\max }, \\
T_{\max }=0.33 T_{r m}+21.8, \\
T_{r m}=\left(T_{o d-1}+0.8 T_{o d-2}+0.6 T_{o d-3}+0.5 T_{o d-4}+0.4 T_{o d-5}+0.3 T_{o d-6}+0.2 T_{o d-7}\right) / 3.8,
\end{gathered}
$$

where, $T_{o p}$ is the operative temperature, ${ }^{\circ} \mathrm{C} ; T_{\max }$ is the maximum permissible temperature, ${ }^{\circ} \mathrm{C} ; T_{r m}$ is the exponentially weighted running average ambient temperature, ${ }^{\circ} \mathrm{C} ; T_{o d-1}$ is the daily average ambient temperature for the day before, ${ }^{\circ} \mathrm{C} ; \mathrm{T}_{o d-2}$ is the daily average ambient temperature for the day before the previous day, ${ }^{\circ} \mathrm{C}$.

The second criterion is that the hours when the operative temperature in the bedrooms from $10 \mathrm{pm}$ to $7 \mathrm{a}$.m. is bigger than $26^{\circ} \mathrm{C}$ shall not be more than $1 \%$ of annual hours ( $33 \mathrm{~h}$ ).

\section{Typical Residential Building in Norway}

Figure 2 shows the typical newly-built Norwegian residential building studied in this paper. Facades are shown in the Figure 3. Figure 4 presents the layout of the first floor. Kitchen and dining room are located on the first floor. Figure 5 shows the layout of the second floor. Three bedrooms are located on the second floor. One typical bedroom (highlighted in Figure 1) is selected to simulate indoor comfort in this study. In the different orientations (south and north), this bedroom can be used to show the different situations. The total floor area is $130 \mathrm{~m}^{2}$. U-values of the building envelope components (minimum requirements in TEK 17) are listed in Table 1. Internal shading with roller blinds was assumed for windows. The window consists of an insulated frame and two-layer glass with argon in the cavity with $1.2 \mathrm{~W} /\left(\mathrm{m}^{2} \mathrm{~K}\right)$. The external wall is insulated by $20 \mathrm{~cm}$ mineral wool. The roof is insulated by $30 \mathrm{~cm}$ mineral wool. The floor is insulated by $30 \mathrm{~cm}$ extruded polystyrene (XPS). As there are no cooling devices in the building studied, the design parameters of infiltration rates are very important for the indoor comfort. Three scenarios $\left(0.0001 \mathrm{~m}^{3} / \mathrm{s} \mathrm{per}^{2}\right.$ facade-tight building, $0.0003 \mathrm{~m}^{3} / \mathrm{s}$ per $\mathrm{m}^{2}$ facade-average building, and $0.0006 \mathrm{~m}^{3} / \mathrm{s}$ per $\mathrm{m}^{2}$ facade-general building) were investigated in this study. The window-to-wall ratio (WWR) is the definition of the fraction on dividing the window area by the external wall area. Four WWR scenarios $(0.35,0.5,0.75$ and 0.9$)$ were simulated. In addition, two orientations (south and north) and three weather conditions (present-day, 2050 and 2080) were the inputs for the simulation. There were 72 scenarios in total based on the parameters mentioned in this study. 


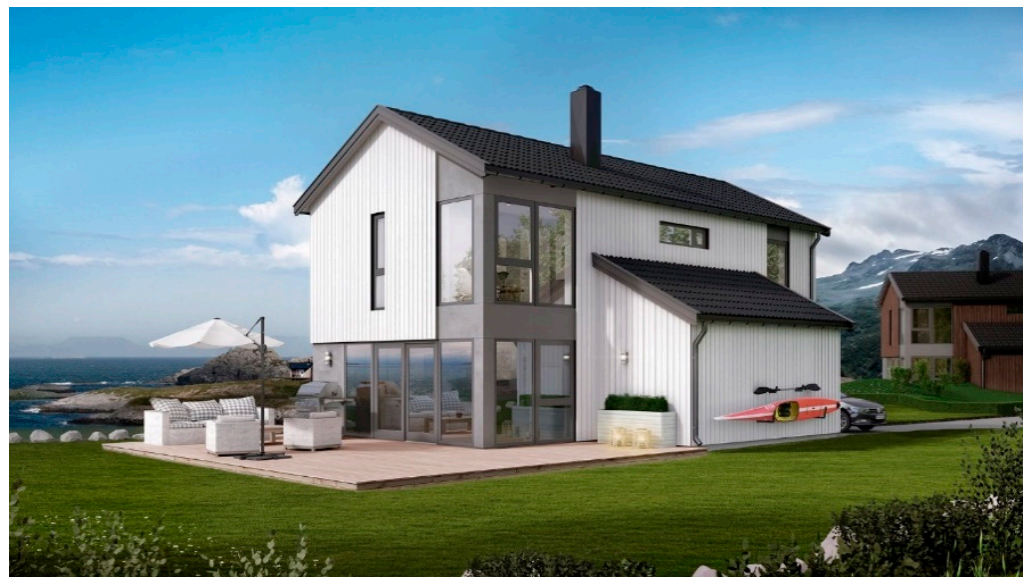

Figure 2. Typical residential building in Norway (Source: Norgeshus).
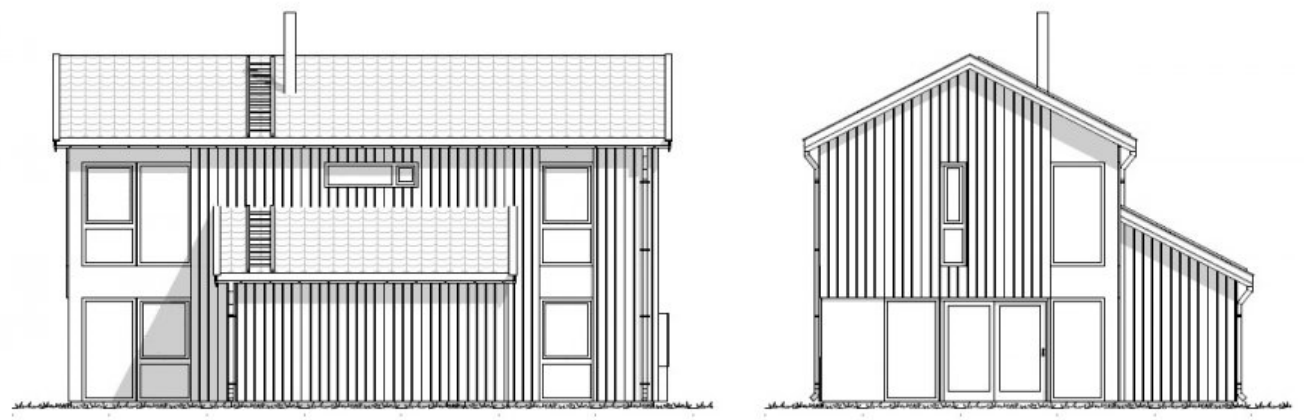

Figure 3. Typical residential building in Norway, facades (Source: Norgeshus).

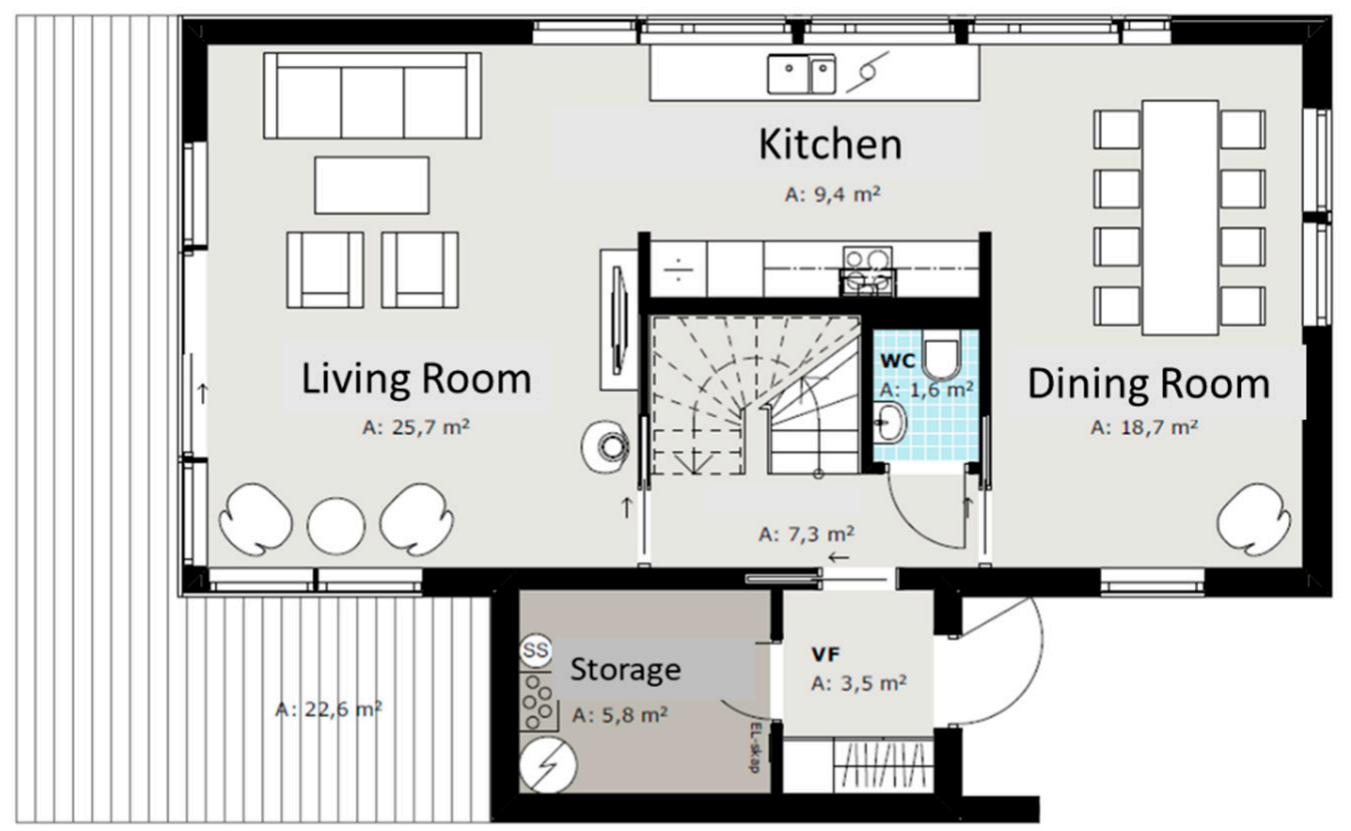

Figure 4. Layout of the first floor (Source: Norgeshus). 


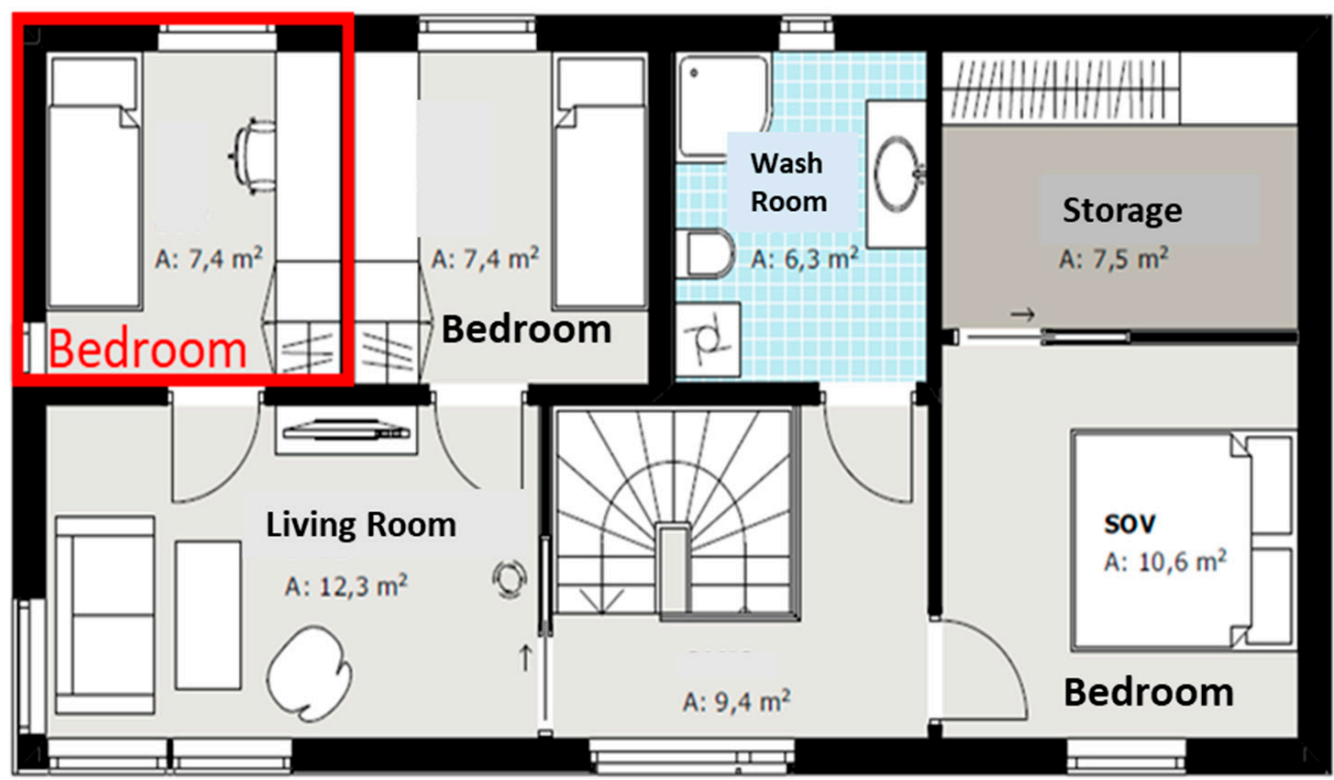

Figure 5. Layout of the second floor (Source: Norgeshus).

Table 1. Building envelope components.

\begin{tabular}{ccccc}
\hline & External Wall & Ground Floor & Roof & Window \\
\hline U-Value $\left(\mathrm{W} /\left(\mathrm{m}^{2} \mathrm{~K}\right)\right)$ & 0.22 & 0.18 & 0.18 & 1.2 \\
\hline
\end{tabular}

\section{Weather Scenarios}

Figure 6a shows the present-day hourly dry bulb temperature in Oslo, Norway. It can be found that the temperatures of few days from 1 May to 30 September can be higher than $30{ }^{\circ} \mathrm{C}$ Currently only few residential buildings have cooling devices installed. Figure $6 \mathrm{~b}, \mathrm{c}$ shows the hourly dry bulb temperature in Oslo in the future, in 2050 and 2080 respectively. In Figure 6c, it can be seen that the temperatures in the hottest days are expected to rise to close to $35{ }^{\circ} \mathrm{C}$, which are similar to the temperatures in the hot summers of 2018 and 2019 in Norway. Heat waves experienced during the summer of 2018 and 2019 may become very commonplace by 2080. The simulated indoor comfort in 2080 may provide some references to design strategies for the extreme hot summer conditions.

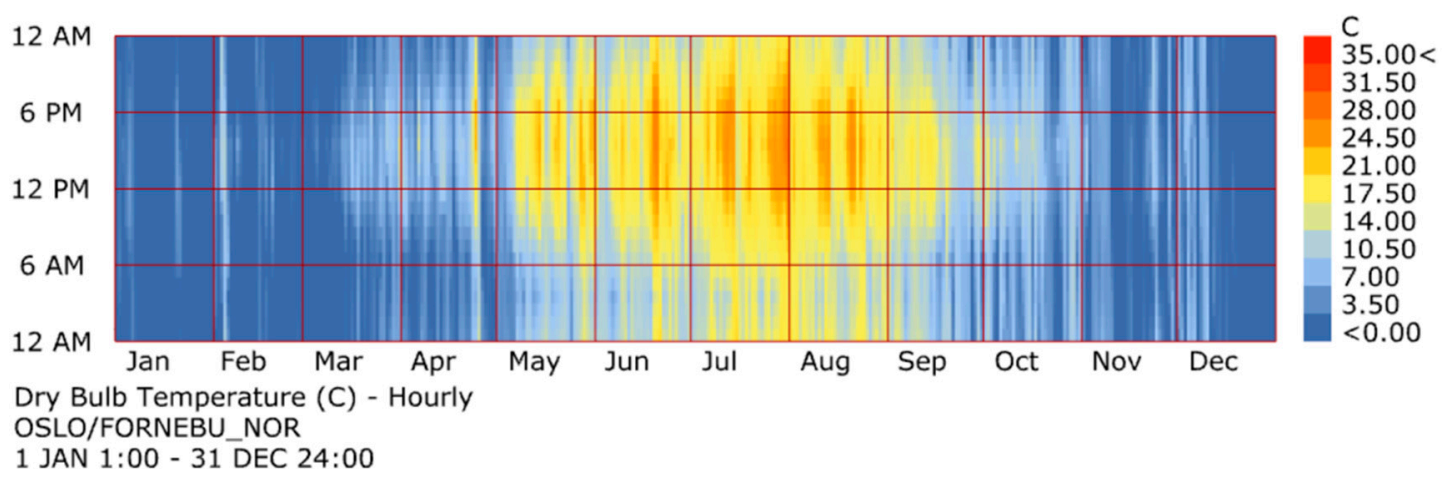

(a)

Figure 6. Cont. 


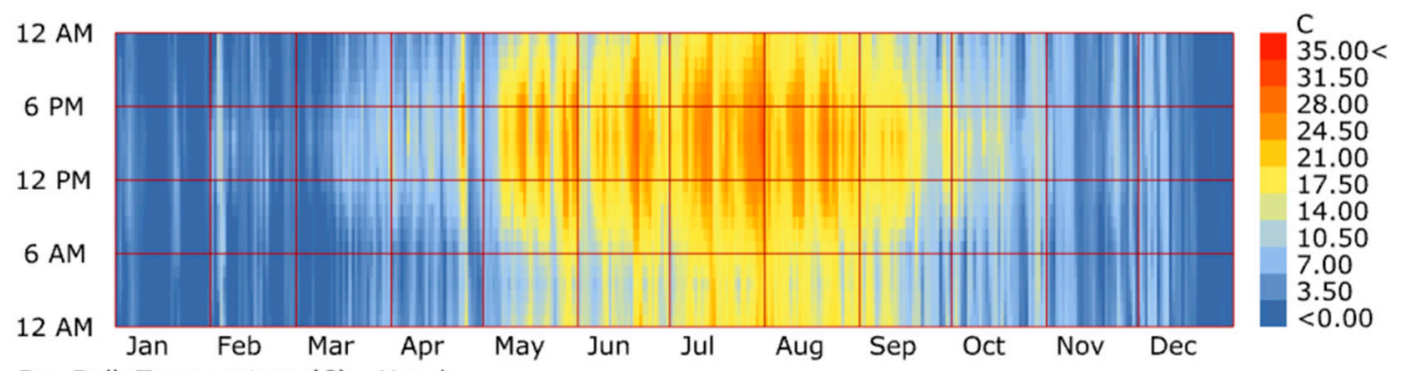
Dry Bulb Temperature (C) - Hourly OSLO/FORNEBU_NOR 1 JAN 1:00-31 DEC 24:00

(b)

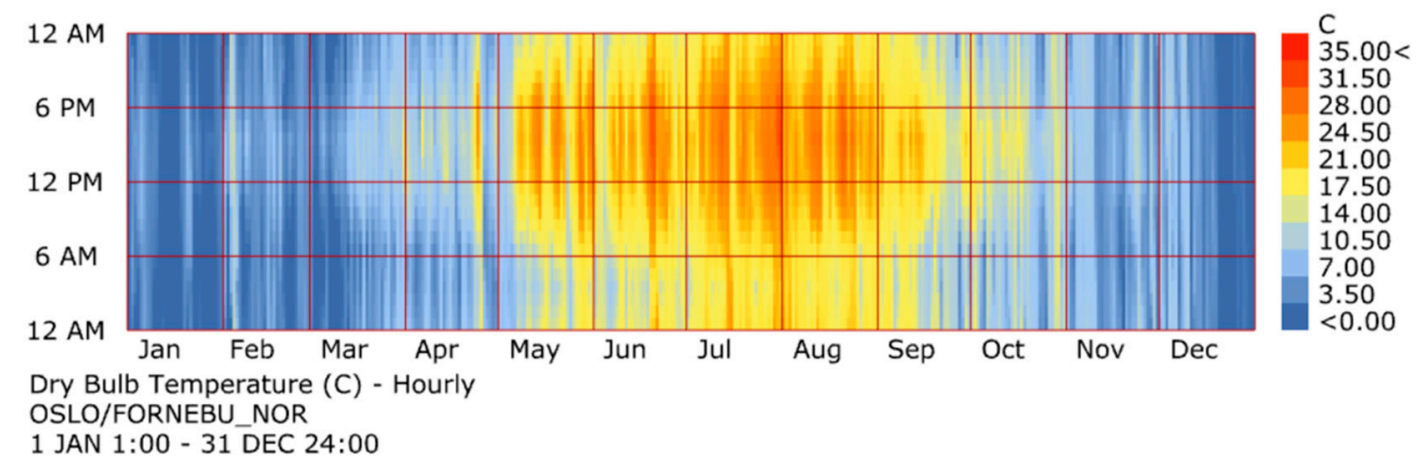

(c)

Figure 6. Hourly dry bulb temperature during one year in Oslo, Norway (a) present-day weather file, (b) 2050 weather file, (c) 2080 weather file.

\section{Results and Discussion}

\subsection{PHPP Method}

Figure 7 shows the annual percentage beyond the acceptable temperature $25{ }^{\circ} \mathrm{C}$ of the tight building model $\left(0.0001 \mathrm{~m}^{3} / \mathrm{m}^{2}\right)$. By comparison, the annual overheating percentage of the bedroom with a southern orientation is 1.5 times more than that of the bedroom with a northern orientation. Modern buildings trend to be designed with a higher window-to wall ratio (WWR). It can be seen that the overheating risk increases with the growth of the window-to-wall ratio, based on the PHPP method. Under the present-day weather conditions, the scenarios with WWR 0.35 and WWR 0.5 have no overheating risk, while the scenarios with WWR 0.75 and WWR 0.9 have obvious overheating risk based on the PHPP method. The scenarios with higher WWR also have higher heating loss in the Norwegian winter. The solar radiation resource is low and the solar gains in winter are low as well. Thus, it is not recommended to use a WWR that is too big in Norwegian buildings, based on the PHPP method.

Figure 8 shows the annual percentage beyond the acceptable temperature of $25^{\circ} \mathrm{C}$ of the average building model $\left(0.0003 \mathrm{~m}^{3} / \mathrm{m}^{2}\right.$ ). In the Figure 8, the room with a southern orientation (WWR 0.75 and WWR 0.9) has higher than $10 \%$ percentage beyond the acceptable temperature, except in the scenario with a WWR of 0.75 under the present-day weather condition.

Figure 9 shows the annual hours and percentage beyond the acceptable temperature of $25^{\circ} \mathrm{C}$ for the general building model $\left(0.0006 \mathrm{~m}^{3} / \mathrm{m}^{2}\right)$. As shown in Figure 9, there are less overheating hours in the less tight building model based on the PHPP method. When the WWR is 0.9 , the overheating percentages of the three building models are similar. If the bedroom with a southern orientation has the smallest WWR of 0.35 , the higher infiltration can reduce the overheating risk for the bedroom. 
When the bedroom with a southern orientation has a bigger WWR, the high infiltration only reduces the overheating risk slightly.

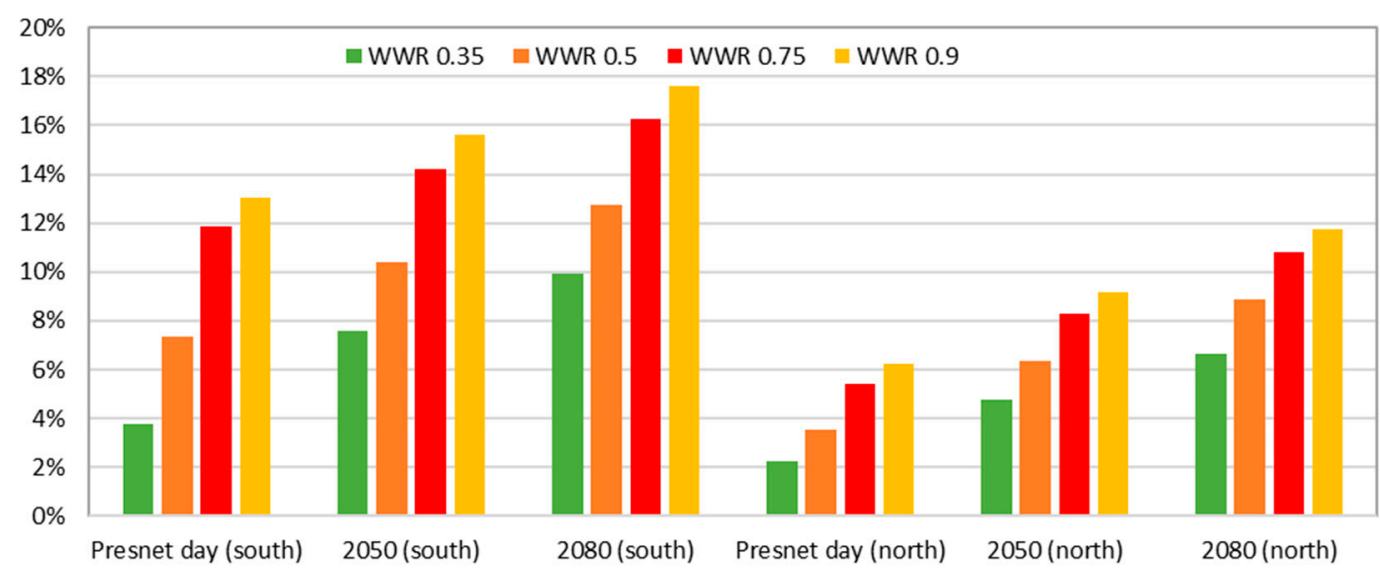

Figure 7. Annual percentage beyond the acceptable temperature $25^{\circ} \mathrm{C}$ (tight building model) based on the Passive House Planning Package (PHPP).

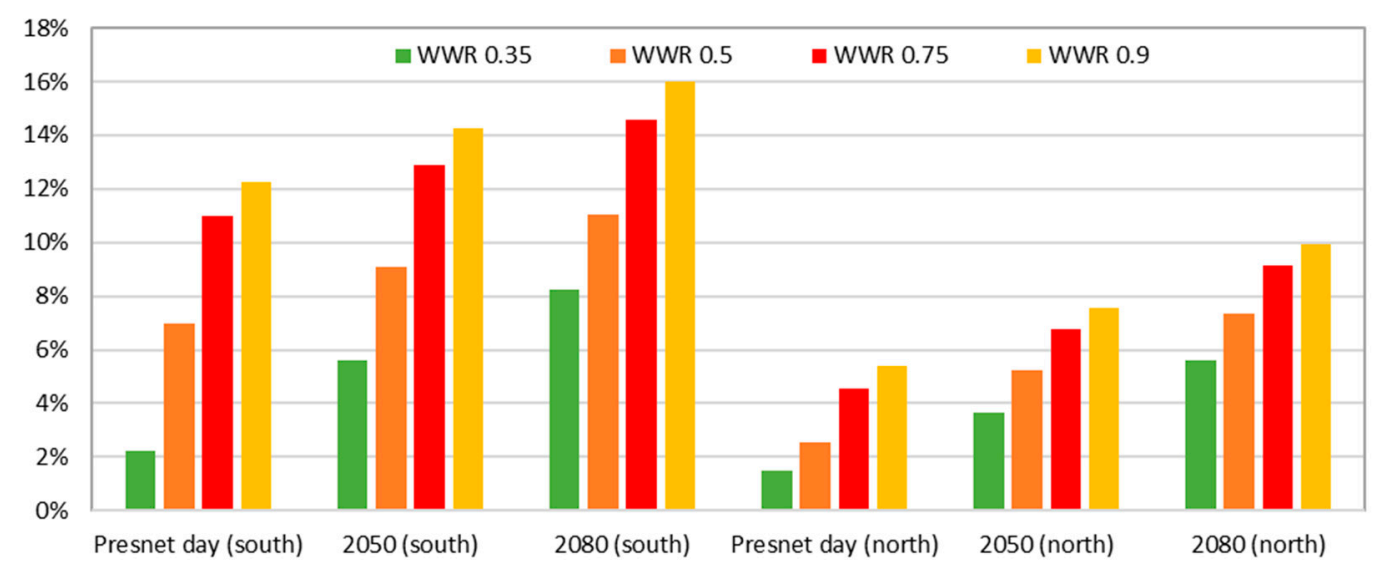

Figure 8. Annual percentage beyond the acceptable temperature $25{ }^{\circ} \mathrm{C}$ based on PHPP (average building).

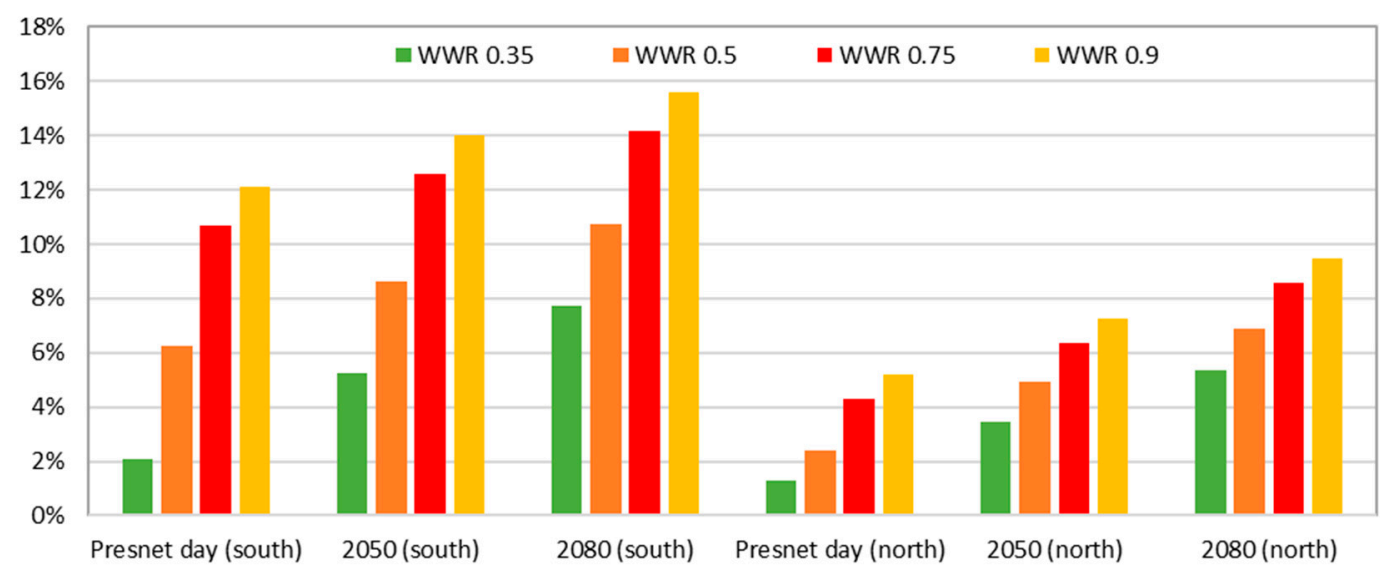

Figure 9. Annual percentage beyond the acceptable temperature $25{ }^{\circ} \mathrm{C}$ based on PHPP (general building). 


\subsection{CIBSE TM 59 (Adaptive Thermal Comfort)}

The operative temperatures during the period of 1 May to 30 September are not more than $1 \mathrm{~K}$ higher than the maximum permissible temperature. The indoor climate conditions of the studied bedroom meet the criterion 1 of the CIBSE TM 59 (adaptive thermal comfort). Figures 10-12 show the accumulative hours with temperatures exceeding $26^{\circ} \mathrm{C}$ during the occupied period (criterion 2 of CIBSE TM 59). In contrast to the results shown in Figures 7-9, the room with a northern orientation tends to have more severe overheating risk than the room with a southern orientation. That is because all hourly indoors temperatures based on the annual basis are considered in the PHPP method. There are many hours with high temperatures during the daytime in the summer seasons. Only the occupied time of the bedroom (from 10 p.m. to 7 a.m.) is taken into consideration in the CIBSE TM 59 method (adaptive thermal comfort). The indoor temperature decreases to below $26^{\circ} \mathrm{C}$ during the night time. For the scenarios with bedrooms with a northern orientation, the bedroom keeps warm from 10 p.m. to 7 a.m. due to the late sunset in the most of Norway in the summer season. In addition, the bedroom has a western wall with window. The bedroom with a southern orientation does not tend to have overheating risk, except in the scenario of the tight building with WWR 0.9, under the 2080 weather conditions. Under the present-day weather conditions, the bedroom with a northern orientation does not tend to have overheating. However, under the future weather conditions (2050 and 2080), the big WWR ratios increase the overheating risk of the bedroom with a northern orientation.

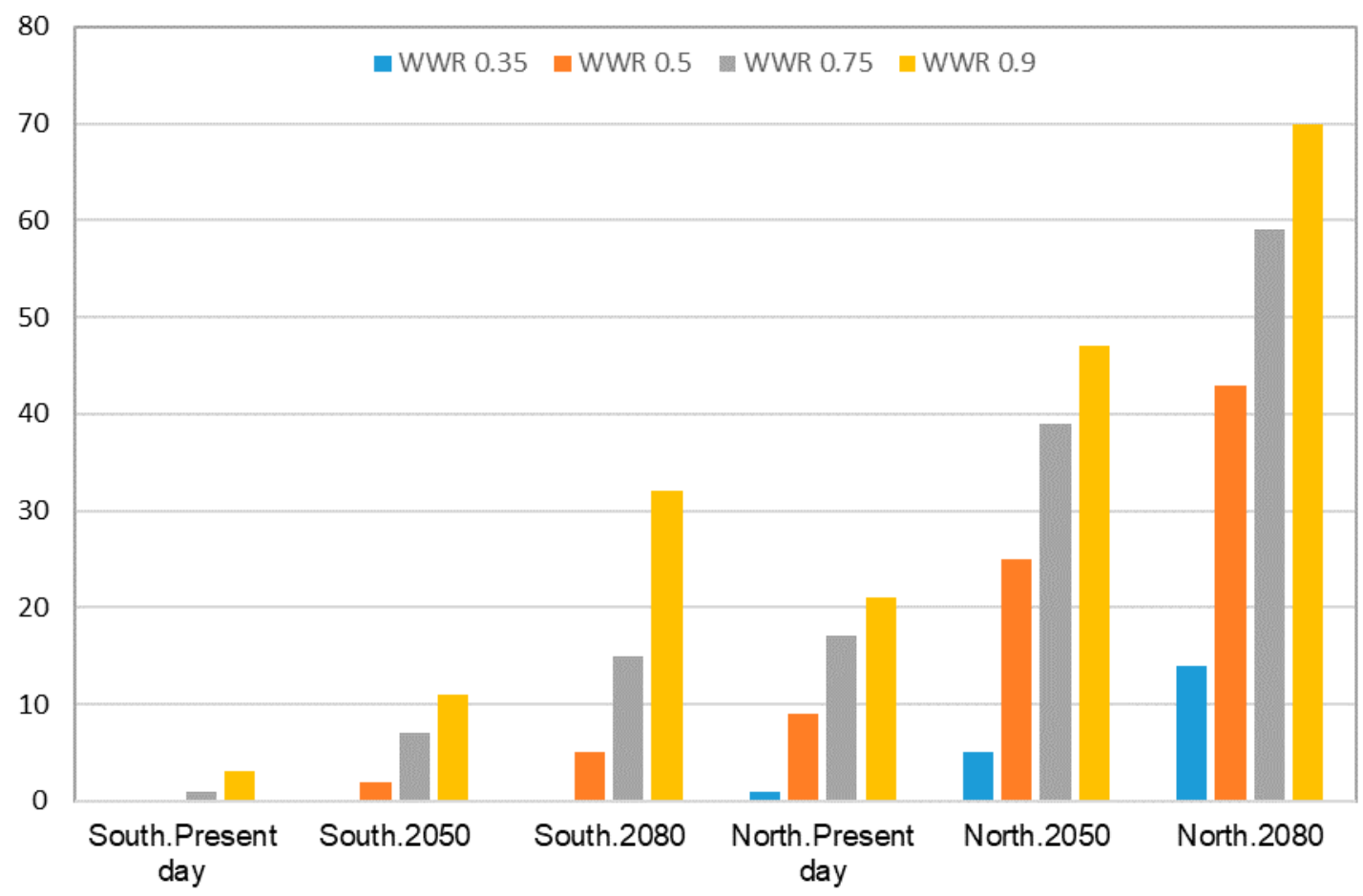

Figure 10. Hours of temperature exceeding $26^{\circ} \mathrm{C}$ during the occupied period based on CIBSE TM 59 (Tight building). 


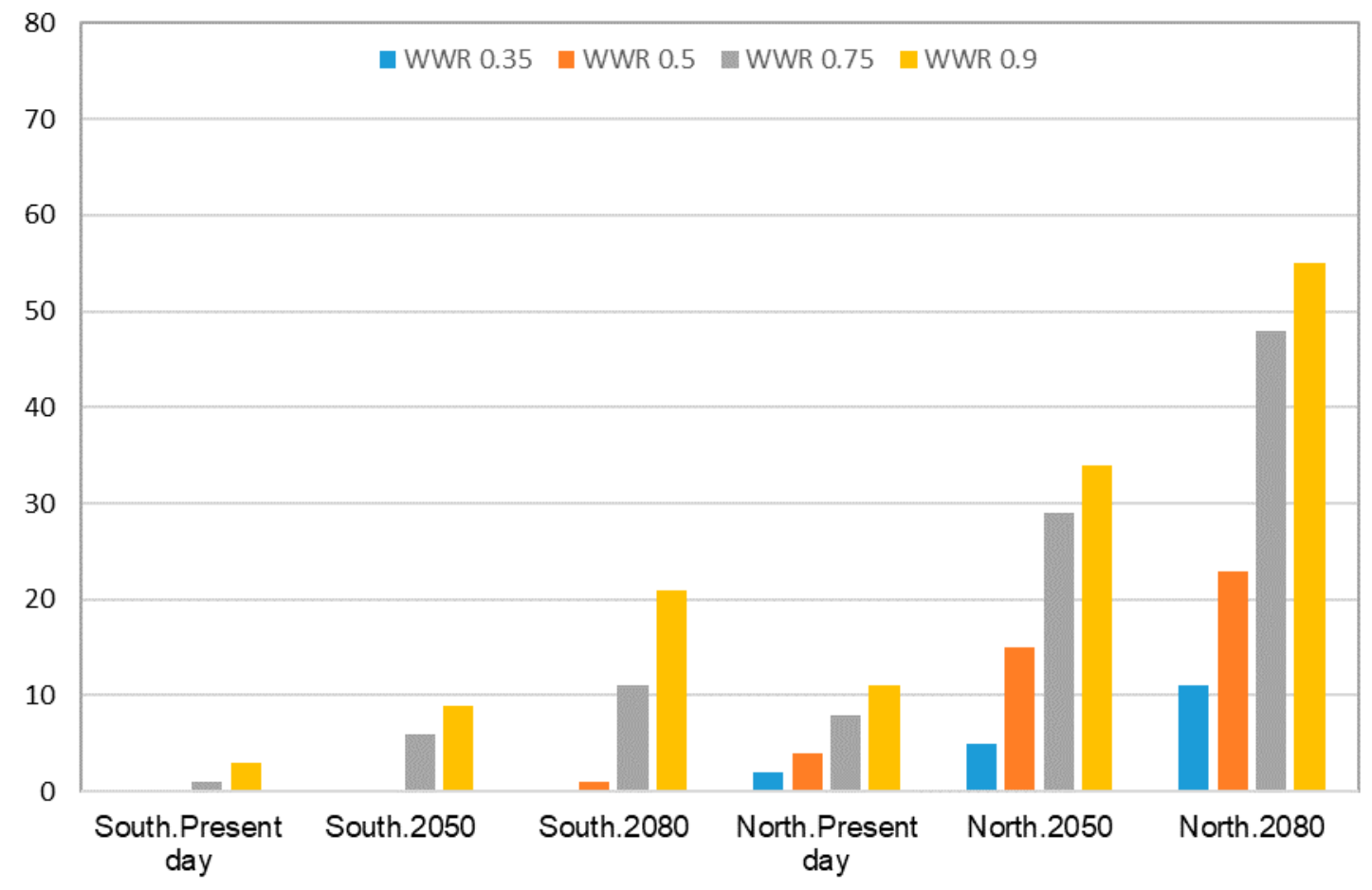

Figure 11. Hours of exceedance $26^{\circ} \mathrm{C}$ during the occupied period based on CIBSE TM 59 (Average building).

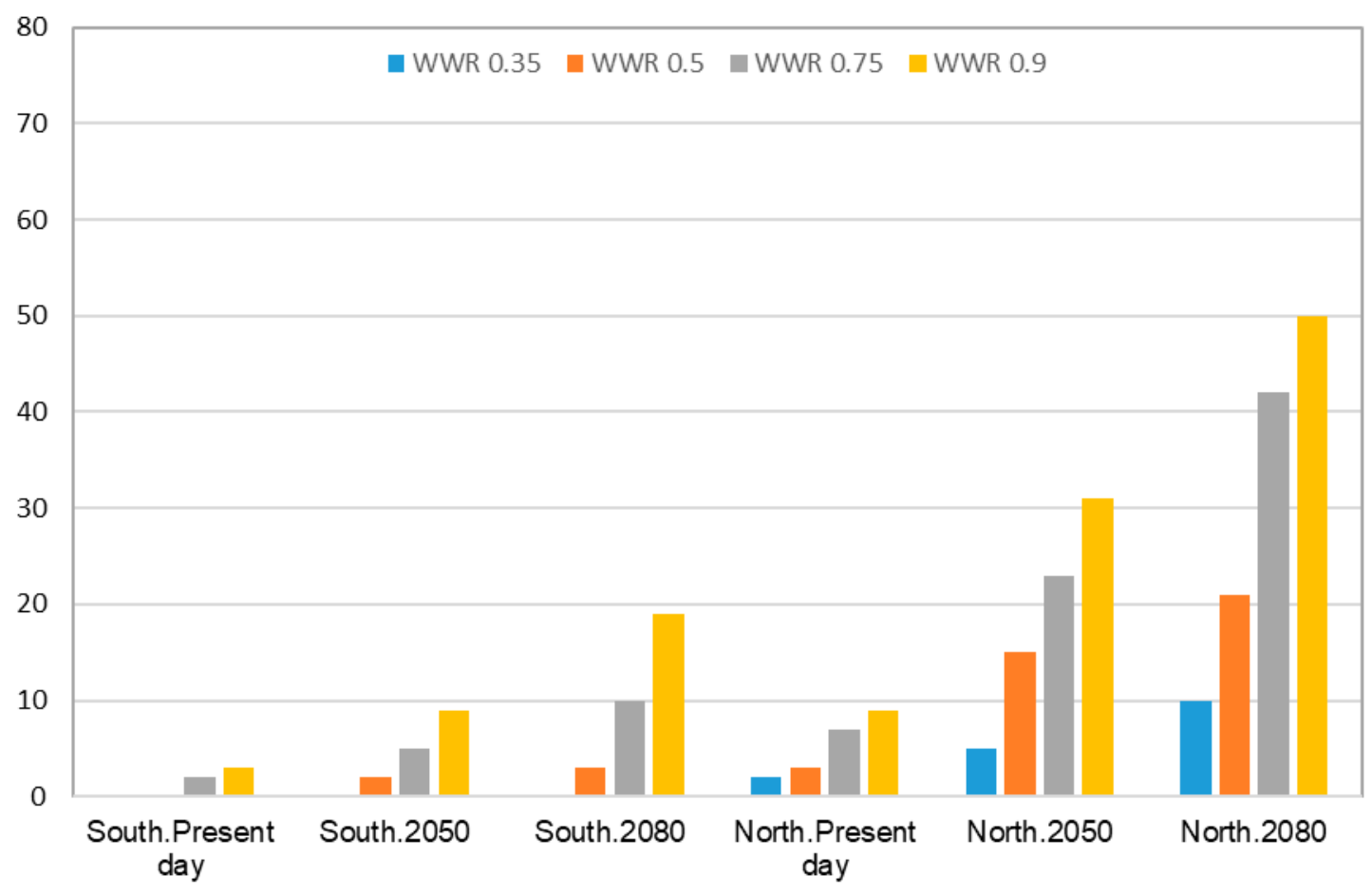

Figure 12. Hours of exceedance $26^{\circ} \mathrm{C}$ during the occupied period based on CIBSE TM 59 (General building).

\section{Conclusions and Outlook}

The overheating risk of a typical Norwegian residential building under present-day, 2050 and 2080 weather conditions was evaluated in this study. Two different overheating evaluation criterial guidelines (the Passive House Planning Package and CIBSE TM 59) were compared. The following conclusions could be drawn: 
1. The evaluation method recommended in the PHPP is not very precise to evaluate the specific overheating risk for bedrooms without considering occupied time. The adaptive thermal comfort method is recommended to evaluate the overheating risk for single rooms in residential buildings.

2. Large window-to-wall ratios (WWR) are not recommended for Norwegian residential buildings. Too large WWR will result in overheating risk in the summer, particularly in the future extreme weather conditions. In the north-western oriented bedrooms with windows faced north, the use of a large WWR is not recommended.

3. In very airtight residential buildings, overheating risk can take place in the future climate scenarios analyzed.

Overheating risks in Norway should be paid attention to, as more and more extreme heatwaves have taken places in recent years. There are mainly two methods, namely passive and active, to tackle the overheating risks. The passive methods are mainly natural ventilation and shading systems. For example, a green roof can be one possible solution to reduce the indoor temperature in the summer seasons due to the shading effect of the plants [20]. The active methods are mainly mechanical cooling devices, such as air-conditioners, and heat dissipation panels [21]. If the passive measures are not enough to reduce the overheating hours, the mechanical methods are required to be installed to keep the indoor environment comfortable.

In future research, the indoor comfort of a typical Norwegian existing residential building retrofitted to the international EnerPHit standard will be investigated. A sensitivity study on other weather parameters, such as diffuse solar radiation and direct normal irradiation (DNI), and wind speed, will be done in future work.

Author Contributions: Z.T. proposed the structure of the paper. Z.T. wrote the paper. S.Z. and J.D. contributed to the model and proofread of the paper. B.D.H. contributed to formulating and developing of the research question and proofread of the paper. All authors have read and agree to the published version of the manuscript.

Funding: The authors would like to acknowledge the Norwegian University of Science and Technology (NTNU), the Faculty of Engineering and the Department of Civil and Environmental Engineering for financial support for the research.

Acknowledgments: Norgeshus provides the information of the typical building model analyzed. Thanks are expressed to Tobias Skov Pedersen from the Technical University of Denmark for the hints on the software.

Conflicts of Interest: The authors declare no conflict of interest.

\section{References}

1. Copernicus Climate Change Service. Available online: https://cds.climate.copernicus.eu/\#!/home (accessed on 1 April 2019).

2. Hughes, C.; Natarajan, S. Summer thermal comfort and overheating in the elderly. Build. Serv. Eng. Res. Technol. 2019, 40, 426-445. [CrossRef]

3. Åström, D.O.; Forsberg, B.; Ebi, K.L.; Rocklöv, J. Attributing mortality from extreme temperatures to climate change in Stockholm, Sweden. Nat. Clim. Chang. 2013, 3, 1050-1054. [CrossRef]

4. Pathan, A.; Mavrogianni, A.; Summerfield, A.; Oreszczyn, T.; Davies, M. Monitoring summer indoor overheating in the London housing stock. Energy Build. 2017, 141, 361-378. [CrossRef]

5. Jenkins, D.; Ingram, V.; Simpson, S.; Patidar, S. Methods for assessing domestic overheating for future building regulation compliance. Energy Policy 2013, 56, 684-692. [CrossRef]

6. Ozarisoy, B.; Elsharkawy, H. Assessing overheating risk and thermal comfort in state-of-the-art prototype houses that combat exacerbated climate change in UK. Energy Build. 2019, 187, 201-217. [CrossRef]

7. Sameni, S.M.T.; Gaterell, M.; Montazami, A.; Ahmed, A. Overheating investigation in UK social housing flats built to the Passivhaus standard. Build. Environ. 2015, 92, 222-235. [CrossRef]

8. Ji, Y.; Fitton, R.; Swan, W.; Webster, P.; Swan, W. Assessing overheating of the UK existing dwellings-A case study of replica Victorian end terrace house. Build. Environ. 2014, 77, 1-11. [CrossRef]

9. Gupta, R.; Gregg, M.; Gregg, M. Preventing the overheating of English suburban homes in a warming climate. Build. Res. Inf. 2013, 41, 281-300. [CrossRef] 
10. Peacock, A.; Jenkins, D.; Kane, D. Investigating the potential of overheating in UK dwellings as a consequence of extant climate change. Energy Policy 2010, 38, 3277-3288. [CrossRef]

11. Psomas, T.; Heiselberg, P.; Duer, K.; Bjørn, E. Overheating risk barriers to energy renovations of single family houses: Multicriteria analysis and assessment. Energy Build. 2016, 117, 138-148. [CrossRef]

12. Ibrahim, A.; Pelsmakers, S.L. Low-energy housing retrofit in North England: Overheating risks and possible mitigation strategies. Build. Serv. Eng. Res. Technol. 2018, 39, 161-172. [CrossRef]

13. Sehizadeh, A.; Ge, H. Impact of future climate change on the overheating of Canadian housing retrofitted to the passivehaus standard. In Proceedings of the 2009 IBPSA Conference, Glasgow, Scotland, 27-30 July 2009.

14. De Grussa, Z.; Andrews, D.; Lowry, G.; Newton, E.J.; Yiakoumetti, K.; Chalk, A.; Bush, D. A London residential retrofit case study: Evaluating passive mitigation methods of reducing risk to overheating through the use of solar shading combined with night-time ventilation. Build. Serv. Eng. Res. Technol. 2019, 40, 389-408. [CrossRef]

15. Salem, R.; Bahadori-Jahromi, A.; Mylona, A. Investigating the impacts of a changing climate on the risk of overheating and energy performance for a UK retirement village adapted to the nZEB standards. Build. Serv. Eng. Res. Technol. 2019, 40, 470-491. [CrossRef]

16. Mitchell, R.; Natarajan, S. Overheating risk in Passivhaus dwellings. Build. Serv. Eng. Res. Technol. 2019, 40, 446-469. [CrossRef]

17. Petrou, G.; Symonds, P.; Mavrogianni, A.; Mylona, A.; Davies, M. The summer indoor temperatures of the English housing stock: Exploring the influence of dwelling and household characteristics. Build. Serv. Eng. Res. Technol. 2019, 40, 492-511. [CrossRef]

18. Roberts, B.M.; Allinson, D.; Diamond, S.; Abel, B.; Das Bhaumik, C.; Khatami, N.; Lomas, K.J. Predictions of summertime overheating: Comparison of dynamic thermal models and measurements in synthetically occupied test houses. Build. Serv. Eng. Res. Technol. 2019, 40, 512-552. [CrossRef]

19. Mlakar, J.; Štrancar, J. Overheating in residential passive house: Solution strategies revealed and confirmed through data analysis and simulations. Energy Build. 2011, 43, 1443-1451. [CrossRef]

20. Schweitzer, O.; Erell, E. Evaluation of the energy performance and irrigation requirements of extensive green roofs in a water-scarce Mediterranean climate. Energy Build. 2014, 68, 25-32. [CrossRef]

21. Zuazua-Ros, A.; Martín-Gómez, C.; Ramos, J.C.; Bermejo-Busto, J. Towards cooling systems integration in buildings: Experimental analysis of a heat dissipation panel. Renew. Sustain. Energy Rev. 2017, 72, 73-82. [CrossRef]

(C) 2020 by the authors. Licensee MDPI, Basel, Switzerland. This article is an open access article distributed under the terms and conditions of the Creative Commons Attribution (CC BY) license (http://creativecommons.org/licenses/by/4.0/). 